\title{
Prioritizing Strategies of Relationship with Retail Customers in Several Levels of Life Cycle by Integrated Approach: KANO-IPA-QFD-TOPSIS
}

\author{
Mehdi Bagheri Ghalenoie ${ }^{1} \&$ Mohammad Hussein Abooie $^{2}$ \\ ${ }^{1}$ Persian Gulf University, Bushehr, Iran \\ ${ }^{2}$ Yazd University, Yazd, Iran \\ Correspondence: Mehdi Bagheri Ghalenoie, Persian Gulf University, Bushehr, Iran. E-mail: \\ mbagherighalenoei@gmail.com \\ Received: April 29, 2016 \\ Accepted: June 24, 2016 \\ Online Published: October 26, 2016 \\ doi:10.5539/mas.v10n11p273 \\ URL: http://dx.doi.org/10.5539/mas.v10n11p273
}

\begin{abstract}
Today, customer orientation and relationship with customers is considered as one of the main strategies of development in organizations. In this regard, it is necessary to create a process that is able of making relationship with different costumers due to their needs and demands. Quality function development (QFD) is one of the common methods regarding to attention to customers' needs and adopting them with definitions and features of costumers in several life cycle levels. In this article, first technical features ( relationship strategies) and relationship needs of retail customers (features of relationship strategies) are recognized; then, strategies of costumers relationship ion each level of life cycle are prioritized using integrated technique of quality QFD and TOPSIS. The results show prioritization of new relationship strategies, especially internet communications compared to other strategies. This study is considered as an efficient step to improve relationship with costumers and as a result, to keep and develop organizations' development status using information gathered from costumers in different levels of life cycle.
\end{abstract}

Keywords: customer relationship, Kano model, importance- performance matrix, TOPSIS, quality function development (QFD)

\section{Introduction}

In modern economy, changes in viewpoints and demands of costumers is considered as one of the most important factors effective on growth or decline process of firms. Organizations that are unaware of costumers' needs and expectations and/or do not understand their real needs, they will lose their market share. Organizations must always supervisor and protector of interaction between organization and its customers to present valuable products and services based on correct recognition and understanding of costumers' needs.

One of problems proposed in organizations about understanding and responding to needs, demands and complaints of customers is lack of using proper relational strategies; thus, identifying and implementing proper methods to communicate with several costumers is an efficient step overcoming this problem. Costumer life cycle is one of the items to classify costumers and attention to their different behaviors; it refers to several time levels that costumers and organization have communication with each other. Identifying levels of customer life cycle has a specific importance due to benefits gained by organization. The relationship between costumers and organization can change due to experiences they gain from each other through time. The more information they have about each other, the more effective is growth and evaluation of their mutual interactions. There are several viewpoints proposed for costumers' life cycle including models presented by Tsiptsis \& Chorianopoulos (2011), Blattberg \& Thomas (2001). Customer equity: Building and managing relationships as valuable assets, Harvard Business Press (2008), Berry and Linoff (2006).

Our case study performed worthy actions in field of relationship with costumers as one of the most powerful food manufacturers In Iran. In this regard, we can refer to CRM unit. Generally, costumers of a firm are classified in three levels of wholesalers, retailers, and final costumers. Though information obtained from opinion of final costumers typically include exact data, but only considering them has usually some problems such as lack of easy access to these costumers. In addition to final costumers, we can study other chains of 
costumes having effective information. Doing this, we can consider entailers as an appropriate option due to benefits below:

1. Retailers are the closest chain to final costumers; thus, they know more about detailed information of costumers.

2. Identification, classification, and making call with retailers are easier than doing this with final costumers.

3. Retailers are final decision maker in relation to shape and range of a brand appearing at retail level; thus, attention to their demands is one of success factors of products at this level.

According to items mentioned above, the importance of retailers in costumer chain is clearly visible and firms must prioritize for relationship with costumers and understanding their demands and viewpoints. The case study is one of the powerful firms with almost 100000 retail member throughout the country; thus, it is necessary to select proper strategies and correct and constructive interaction with this type of costumers.

In this article, we consider prioritizing strategies of relationship with retail customers in several levels of life cycle using TOPSIS integrated approach and QFD. One of the planning tools in QFD is quality unit. Firms are usually facing with some constraints in order to implement quality unit and to prioritize its technical features; therefore, some criterion are proposed to overcome available constraints and to obtain a suitable evaluation of technical features. In this study, TOPSIS multi-criterion decision method is implemented for final prioritization of strategies in several levels of life cycle using criterion determined by experts of the firm and the parameter 'voice of customers'.

\subsection{Theoretical Principles of Research}

\subsubsection{Strategies of Costumer Relationship}

Today, increase in demands and expectations of costumer gives power of selecting relational strategies for them. According to changes in communication technology, firms can focus on several options to communicate with costumers. Payne and Frow (2004) divided firm's relational strategies with costumers to 6 categories of sales power (presenting products in person), sales market (shops and kiosks), distant calls (phone, fax), direct marketing (TV, radio), e-trade (internet, e-mail etc.), and cell phone (call, SMS etc.). Sinisialo (2006) introduces proper strategies to create multiple communication environments including face-to-face communications, telephone, direct marketing, internet, self-service, and cell phone. Of possible strategies of communication with costumers in the studied firm, we can refer to face-to-face communication, post, telephone (call, answering and fax), internet (chat, e-mail, and web site), and cell phone (SMS, call, and MMS). It must be noted that strategies of mutual interaction are considered in this study, each one have some features that could be used for specific goals and applications.

\subsubsection{Features of Face-To-Face Communications}

Face-to-face relation is defined as information, thoughts, and feelings exchange when people are located in an equal spatial situation. Of features of face-to-face relationship are verbal and non-verbal communications, simultaneous relation with costumers, transfer of feelings, and ability of firm to establish a proper interaction atmosphere with costumers, increase in costumers' perception toward organization, possibility of personal communications, making trust, facilitating costumers' evaluation, security, and valuing costumers.

\subsubsection{Features of Internet Communications}

Internet is a global wide network of computers that are connected together for information exchange temporarily. This strategy is suggested when communication costs are important for firm and also firms want to gain information of their costumers continually. In this regard, features of this strategy include : simultaneous and non-simultaneous communications, possibility of 24 hours a day communications, verbal and non-verbal communications, business and non-business communications, personal and public communications, official and non-official communications with exact and clear details, being cheap and cost effective, easy and fast flow of information, online discussions, participation of costumers, presenting information about products, incentive activities, sales and developing interaction with costumers.

\subsubsection{Features of Mobile Communications}

Cell phone is considered as a capable communication channel in business interactions to access costumers; it has several features and benefits including: saving in time and cost, providing personal relations, presenting on time information to costumers, possibility of making first call by costumers, personal access to people everywhere and anytime, easy following, ease of use and its high response rate, permanent access to costumers, and high security. 


\subsubsection{Classification Models of Qualitative Features (Costumers' Needs And Demands)}

There are several models for rating needs and expectations of costumers including models of Herzberg (2011),Zhang and Dran (2000),Swan and Combs (1976), Kano et al (1984), Brechan (2006), Cadotte and Turgeon (1988), and Oliver. In this regard, Kano's model is recognized as one of the perfect model sin field of classifying customers" needs; it is still one of the most applied methods of the filed despite presenting new models. Firms might face with some problems when using this model such as lack of consistence between priorities presented for costumers' needs and firm's strengths and weaknesses. Accordingly, Wu et al (2010) proposed Kano integrated model and importance-performance matrix to solve this problem. They specified key factors for success of a Taiwanese firm using Kano's integrated model and importance-performance matrix. Therefore, they focused on determining classifications mentioned by Kano's model in addition to determining priorities, importance of these factors and firm's performance from costumers' perspective.

\subsubsection{Quality Function Deployment (QFD)}

QFD is a Japanese term translated to English as 'quality function deployment'; QFD makes organizations able to identify and remove problem before complaint of costumers. Thakkar et al (2006) perceive QFD as a customer-oriented design process responding to questions of 'what' and 'how' due to voice of costumers. In this technique, quality is broken to operative, manageable, and sensible actions to ensure providing costumers' needs at appointed time.

The first tool of planning used in QFD is quality unit; it transforms voice of costumer to design requirements. Most of mangers and engineers know quality unit as the first diagram in quality planning. Quality unit is a matrix determining the relation between 'what' and 'how' so that 'what' includes demands and needs of customers of products or services (costumer necessities), and 'how' determines presenting costumers' demands of product (technical necessities).

\subsubsection{TOPSIS Method}

TOPSIS is of one of the reparative multi-criterion decision models locating in compromise subgroup; it was suggested by Hwang and Yoon in 1981; this is one of the best and simplest multi-criteria decision models. In this method, ' $m$ ' options are evaluated by ' $n$ ' indicators. Generally, fundamental reality of this method is as below:

A. Utility of each indicator must be uniformly increasing or decreasing, so that the best value of an indicator shows positive ideal and the worth value shows negative ideal.

B. Distance of an option from positive ideal (or negative one) might be calculated as Euclidean distance and/or total absolute value from linear distances; this depends on exchange rate and replacement between indicators.

\section{Literature Review}

AL-Majali and Prigmore (2010) studied about used of online communication strategies in order to contact with costumers. The results showed that costumers' interest to achieve online services is more than that of offline one due to features of online services. Dakora (2007) presented multi-criterion strategies to sell products regarding growth strategy of firms. In this regard, he assessed strategies such as post, retailing, fairs, telephone (call center), internet, TV, reseller, and cell phone from costumers' viewpoint. One of the results of this research is difference between priorities of strategies on one hand, and different classifications of costumers on the other. Dfelice and Petrillo (2007) used an adoptive AHP, QFD model to evaluate needs of customers. They used AHP model in order to prioritize costumer needs and technical features emphasizing that multi-criterion decision techniques have logical approach and proper weighting and priority accuracy. Murad (2009) identified ways of improving communication of OLDI co. with retail customers. According to marketing strategies such as verbal contact, web site, e-mail, seminar and conference, advertisement and public relations, it was found that modern communication strategies like website and e-mail are interested by most costumers due to their proper informative aspect; it is possible to improve interaction between costumers and organization with cultural intentions. Najmi et al (2009) prioritize technical and engineering features of Fuzzy QFD model using TOPSIS method. In this research, they limit quality matrix to the weight related to costumers' demands and the relation between their demands and technical features; then, they prioritize technical features sing TOPSIS and weights obtained in fuzzy mood.

\section{Research Method}


This research is of applied type due to desired goals; it is also of survey type since it determines beliefs and viewpoints of costumers in association with relational features. The area of his research is Yazd city and population includes all retailers and sales experts of company interest. The sampling of this study is simple random and the population equal to 278 persons using Morgan table. Also 4 experts of firm were consulted to evaluate relational features and strategies. Doing this research, first relational features and strategies are identified through library studies and those features and strategies are determined that sound suitable in level of retail customers. Then, features of interest of costumers are identified and prioritized (priority requirements) in each level using Kano questionnaire and performance-importance matrix; at last, QFD and TOPSIS strategies are prioritized using mix method.

\subsection{Kano Integrated Model and Performance-Importance Matrix}

To implement this model, it is necessary to recognize Kano levels for each qualitative feature; then, we determine position of each feature in performance-importance matrix. To determine Kano levels for each feature, the standard questionnaire of this model is used including binary questions about the presence or absence of related feature. Wave et al used a mix questionnaire and also Kano questionnaire simultaneously to measure importance of success factors. accordingly, it is possible to measure importance of each feature simultaneously so that 'I am completely agree' and 'I am completely disagree' are the most $(=5)$ and the least $(=1)$ important weights, respectively. Thus, position of each feature is determined in performance -importance matrix; they are prioritized due to their location in the desired matrix and also Kano model. Finally, we emphasize on factors of customer satisfaction due to proper function of firm considering current strategy; thus priority of qualitative features in these locations is $\mathrm{A}>\mathrm{O}>\mathrm{M}>\mathrm{I}$. also if some of these factors are joint in one area of Kano levels, we can consider the importance weight of each factor for prioritization. For features located in $3^{\text {rd }}$ and $4^{\text {th }}$ regions due to improper function of firm, we should focus on basic needs of costumers and assign resources of firm for this purpose. Thus, the priority of features in this locations is $\mathrm{M}>\mathrm{O}>\mathrm{A}>\mathrm{I}$.

\subsection{TOPSIS-QFD Integrated Model}

Using QFD method, technical features are prioritized due to attention just to costumers' viewpoints and determining the relation between features and costumers' needs. In this regard, quality home matrix determines the relation between these definitions and technical features and costumer needs. But to obtain a proper response for prioritization of technical features, it is necessary to focus on factors such as competitive evaluation (costumer-technical), value of goal and ... that are components of this method. Due to limit of interaction with costumers, it is not possible to propose most of these factors making their relationship complicated. We can attend to parameters of technical evaluation to compensate these constraints. Though most important parameter of decision making is costumers' opinions but condition and constraints of firm is so determinative for their evaluation and prioritization. Also weights obtained by quality home matrix are considered as weights of voice of costumers (results of feature prioritization using QFD method) in final prioritization of technical features through TOPSIS. Members of QFD team were used as experts and decision makers to determine weight of parameters. In this regard, final weight of parameters is determined using related questionnaire and calculating average of obtained answers.

\subsection{Case Study}

As said before, one of dominant firms in food industry was used to implement proposed model regarding prioritization of strategies of relationship with costumers in several levels of life cycle. The referred firm is one of the powerful firms in field of food products with 100000 retail costumers; the firm focuses on interaction with this level of costumers considering the importance of retailers in presenting their products as an intermediate between firm and final consumers.

\subsection{Identification of Retailers' Needs in Several Levels of Life Cycle}

a survey of food retailers was performed in Yazd to prioritize and identify features of relation with costumers in different levels of life cycle (here, life cycle includes probable costumer, new costumer, available costumer, moving out costumer, and former costumer). Accordingly, features of these costumers (retailers) are determined due to opinion of firms' sales experts (Table 1). There were 300 questionnaires distributed to determine costumers' status in life cycle model, and also levels of Kano model for each feature and their importance; among them, 251 questionnaires were fulfilled correctly and properly.

To measure stability of questionnaire, Cronbach-Alpha test was used that its value for responses related to performance, presence and absence of relational features is $0.9,0.71$, and 0.9 , respectively. Stability of questionnaire is confirmed since these values are more than 0.7 . 
The assumption 'there is not any meaningful difference between features of relationship with costumers in several levels of life cycle' is studied after identifying costumers and before determining prioritized features of relation with them. To test assumption, non-parametric Kruskal-Wallis test was used. Since p-values of features discussion with firm and multi-person relationship are equal to 0.01 and 0.031 , the assumption is rejected i.e. these features have a meaningful difference against each other in several levels of interaction with costumers. Also, the assumption is accepted for features of relationship with firm, continuity of relationship, presenting incentives, and exact information with p-values of 0.056, 0.063, 0.079, and 0.097, respectively. For other features, zero assumption is accepted with high p-value.

Nevertheless, relational needs of costumers are different in several levels of life cycle due to their behavioral conditions. In the first step of Kano integrated model and performance-importance matrix, Kano levels are determined for each of relational features; meaning that for each of these features, the level with highest frequency would be considered as costumer's need (Table 1). After determining Kano levels, the position of each feature, and then their priority is specified in four areas of performance-importance matrix (Figure 1 and Figure 2). Finally, relational features located in areas 1 and 4 of matrix are considered since success of firm is depended on viewpoints and priorities of costumers. Thus, relational needs of customers in different levels of life cycle are determined.

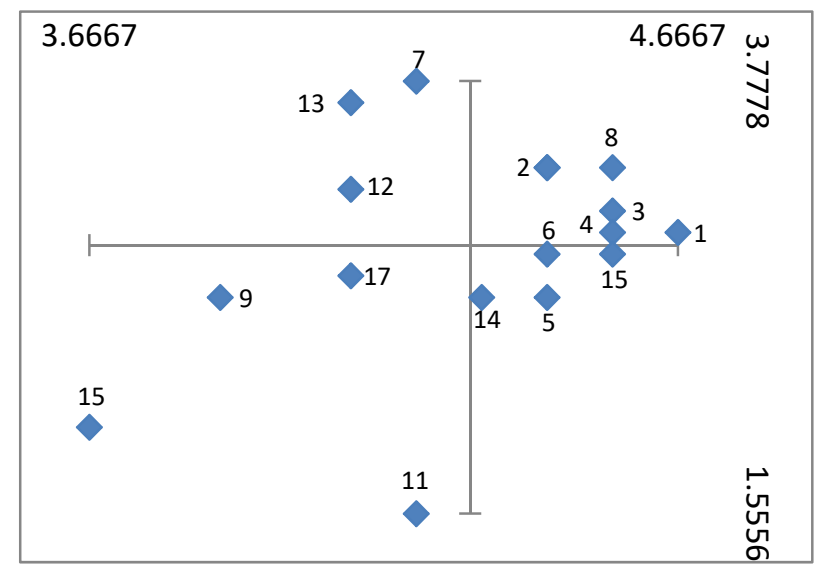

Figure 1. Location of relational features of new customers in importance-performance matrix

\begin{tabular}{|c|c|c|c|c|}
\hline 4.222 & O-7 & \multirow[t]{6}{*}{3.7756} & 4.6667 & A-1 \\
\hline 4.111 & M-12 & & 4.5556 & A-3 \\
\hline \multirow[t]{4}{*}{4.111} & M-13 & & 4.5556 & A- 10 \\
\hline & & & 4.4444 & A-8 \\
\hline & & & 4.5556 & $\mathrm{O}-4$ \\
\hline & & & 4.4444 & M-2 \\
\hline \multicolumn{2}{|l|}{3.6667} & \multirow[b]{5}{*}{1.5556} & \multicolumn{2}{|r|}{4.6667} \\
\hline 4.222 & A-11 & & 4.5556 & O-15 \\
\hline 2.7778 & I-17 & & 4.4444 & A-6 \\
\hline 2.6667 & I-16 & & 4.3333 & A-14 \\
\hline 2 & I-9 & & 4.4444 & I-5 \\
\hline
\end{tabular}

Figure 2. Priority of relational features of new customers in importance-performance matrix 
Table 1. Futures of relation with costumers and Kano classification on different levels of life cycle

\begin{tabular}{|c|c|c|c|c|c|c|c|c|c|c|c|c|c|c|c|}
\hline \multirow{2}{*}{ Life cycle level } & \multicolumn{3}{|c|}{$\begin{array}{l}\text { Probable } \\
\text { customer }\end{array}$} & \multicolumn{3}{|c|}{ New customers } & \multicolumn{3}{|c|}{$\begin{array}{l}\text { Current } \\
\text { customers }\end{array}$} & \multicolumn{2}{|c|}{$\begin{array}{l}\text { Moving } \\
\text { customers }\end{array}$} & out & \multicolumn{3}{|c|}{$\begin{array}{l}\text { Former } \\
\text { customers }\end{array}$} \\
\hline & $\mathrm{CR}$ & I & $\mathrm{O}$ & $\mathrm{CR}$ & I & $\mathrm{O}$ & $\mathrm{CR}$ & I & $\mathrm{O}$ & $\mathrm{CR}$ & I & $\mathrm{O}$ & $\mathrm{CR}$ & I & $\mathrm{O}$ \\
\hline $\begin{array}{l}\text { 1. Possibility of } \\
\text { discussion with firm }\end{array}$ & I & 3.94 & & $\mathrm{~A}$ & 4.67 & 3 & $\mathrm{M}$ & 4.28 & 3.17 & I & 3 & 2.2 & I & 3.92 & 2.31 \\
\hline $\begin{array}{l}\text { 2. Ease of relation } \\
\text { with firm }\end{array}$ & $\mathrm{O}$ & 4.76 & & $\mathrm{M}$ & 4.44 & 3.33 & $\mathrm{O}$ & 4.43 & 3.45 & I & 3.8 & 2.6 & $\mathrm{O}$ & 4.23 & 3.23 \\
\hline 3. Cost-effective & $\mathrm{O}$ & 4.59 & & A & 4.55 & 3.11 & A & 4.36 & 3.30 & $\mathrm{O}$ & 4.2 & 2.2 & I & 4.8 & 2.77 \\
\hline 4. Time saving & I & 4.35 & & $\mathrm{O}$ & 4.55 & 3 & I & 4.32 & 3.27 & I & 3.8 & 2.6 & I & 4.08 & 2.69 \\
\hline $\begin{array}{l}\text { 5. Making contact } \\
\text { anytime/ anywhere }\end{array}$ & I & 3.94 & & I & 4.44 & 2.67 & I & 4.25 & 3.11 & I & 3.4 & 3.2 & I & 4.31 & 2.54 \\
\hline 6. Being responsive & $\mathrm{O}$ & 4.65 & & A & 4.44 & 2.89 & $\mathrm{O}$ & 4.41 & 2.96 & A & 4.4 & 3 & $\mathrm{M}$ & 4.23 & 2.46 \\
\hline $\begin{array}{l}\text { 7. Lack of } \\
\text { disturbance }\end{array}$ & $\mathrm{O}$ & 4.35 & & $\mathrm{O}$ & 4.22 & 3.78 & $\mathrm{I}$ & 4.24 & 3.33 & I & 4 & 3 & I & 4.15 & 2.77 \\
\hline $\begin{array}{l}\text { 8. Non-verbal } \\
\text { relation }\end{array}$ & A & 4.35 & & A & 4.44 & 3.33 & I & 4.23 & 3.26 & M & 4.4 & 2.8 & A & 4.46 & 3 \\
\hline 9. Verbal relation & I & 3.59 & & I & 3.88 & 2.67 & $\mathrm{I}$ & 3.81 & 2.27 & I & 3.8 & 2.6 & A & 3.54 & 2.08 \\
\hline $\begin{array}{l}10 . \text { Accessibility of } \\
\text { relational tools }\end{array}$ & I & 4.35 & & A & 4.55 & 3.33 & A & 4.36 & 3.23 & A & 4.6 & 3.8 & I & 3.85 & 3.08 \\
\hline $\begin{array}{l}\text { 11. Presenting } \\
\text { entertainment }\end{array}$ & A & 3.94 & & A & 4.22 & 1.55 & A & 4.21 & 1.77 & A & 4 & 1.6 & I & 4.08 & 1.61 \\
\hline $\begin{array}{l}\text { 12. Possibility of } \\
\text { poll }\end{array}$ & $\mathrm{M}$ & 4.35 & & $\mathrm{M}$ & 4.11 & 3.22 & I & 4.41 & 2.6 & $\mathrm{O}$ & 4.4 & 3 & $\mathrm{O}$ & 4.38 & 2.54 \\
\hline $\begin{array}{l}\text { 13. Exact } \\
\text { information }\end{array}$ & $\mathrm{M}$ & 4.53 & & $\mathrm{M}$ & 4.11 & 3.67 & A & 4.62 & 3.38 & $\mathrm{M}$ & 4.2 & 3.2 & I & 4.69 & 3.92 \\
\hline $\begin{array}{l}\text { 14. Firm's mention } \\
\text { to customers }\end{array}$ & I & 3.94 & & A & 4.33 & 2.67 & I & 4.18 & 2.17 & I & 3.2 & 2.6 & I & 3.61 & 1.69 \\
\hline $\begin{array}{l}\text { 15. Presenting } \\
\text { incentives }\end{array}$ & $\mathrm{O}$ & 4.82 & & $\mathrm{O}$ & 4.55 & 2.89 & A & 4.58 & 2.22 & I & 4 & 2.2 & $\mathrm{O}$ & 4.31 & 2.23 \\
\hline $\begin{array}{l}\text { 16. many-to-many } \\
\text { relations }\end{array}$ & I & 4.18 & & I & 3.67 & 2 & I & 3.67 & 1.69 & I & 3.4 & 2 & I & 2.85 & 1.38 \\
\hline $\begin{array}{l}\text { 17. Functional } \\
\text { features of firm }\end{array}$ & I & 3.88 & & I & 4.11 & 2.78 & I & 4.07 & 2.65 & I & 3.2 & 2.4 & I & 3.61 & 2.23 \\
\hline $\begin{array}{l}\text { CR: Customer Req } \\
\text { O: Functional Neces }\end{array}$ & sities & & M: E & asic $\mathrm{I}$ & recessI & $\begin{array}{l}\text { tance } \\
\text { ies }\end{array}$ & & $\begin{array}{l}\text { O: } \mathrm{O}_{1} \\
\text { I: Indi }\end{array}$ & $\begin{array}{l}\text { eration } \\
\text { erent }\end{array}$ & & A & Inc & & ece & \\
\hline
\end{tabular}

Table 2. Priority features in each level of costumers' life cycle

\begin{tabular}{|c|c|c|c|c|}
\hline Probable costumers & New costumers & Current costumers & $\begin{array}{lr}\text { Moving out } \\
\text { costumers }\end{array}$ & Former costumers \\
\hline $\begin{array}{l}\text { Exact information } \\
\text { about products and } \\
\text { services }\end{array}$ & $\begin{array}{l}\text { Possibility } \\
\text { discussion } \\
\text { firm }\end{array}$ & $\begin{array}{l}\text { Exact information } \\
\text { about products and } \\
\text { services }\end{array}$ & $\begin{array}{l}\text { Accessibility of } \\
\text { Relational tools }\end{array}$ & $\begin{array}{l}\text { Exact information } \\
\text { about products and } \\
\text { services }\end{array}$ \\
\hline Possibility of poll & Cost-effective & Cost-effective & $\begin{array}{l}\text { Being } \\
\text { responsive }\end{array}$ & Non-verbal relation \\
\hline Presenting incentives & $\begin{array}{l}\text { Accessibility of } \\
\text { Relational tools }\end{array}$ & $\begin{array}{l}\text { Accessibility of } \\
\text { Relational tools }\end{array}$ & Cost-effective & Possibility of poll \\
\hline $\begin{array}{l}\text { Ease of relationship } \\
\text { with firm }\end{array}$ & $\begin{array}{lr}\text { Ease } & \text { of } \\
\text { relationship with } \\
\text { firm }\end{array}$ & $\begin{array}{l}\text { Ease of relationship } \\
\text { with firm }\end{array}$ & & $\begin{array}{l}\text { Ease of relationship } \\
\text { with firm }\end{array}$ \\
\hline $\begin{array}{l}\text { Being responsive } \\
\text { Cost-effective }\end{array}$ & Being responsive & Being responsive & & $\begin{array}{l}\text { Being responsive } \\
\text { Presenting } \\
\text { incentives }\end{array}$ \\
\hline
\end{tabular}


Lack of disturbance

Non-verbal relation

Presenting

entertainment

\subsection{Prioritizing the Strategies of Relation with Costumers in Several Levels of Life Cycle}

According to results obtained by features of strategies of relationship with costumers, there were 11 features specified among 17 proposed ones. It must be noted that 11 features are for all levels of life cycle and as seen in Table 2, relational features are similar in some levels. After determining priority features as relational needs of customers in each level of life cycle, relationship strategies are prioritized using QFD-TOPSIS mix technique; firstly, final weight of matrix elements including strategies as technical features and features as costumers' needs is considered due to frequency of responses of team members for each element. Thus, the priority of relational strategies is determined due to results obtained by communication matrix and weights of features (Kano model and performance-importance matrix).

But as said before, there are some limits to use this method. Therefore, some criteria were implemented by sales experts of firm to compensate these limits. Thus, parameters of cost, function of competitors and technical possibility were considered in addition to criterion of voice of costumers.

Therefore, relational strategies for probable costumers are specified using QFD due to priority features (costumers' needs), Kano model and performance-importance matrix, and determining technical features; finally, technical definitions having most importance to meet costumers' needs are identified. In this regard, absolute weight and percent of each strategy is calculated as below:

$$
a_{j}=\sum_{i=1}^{n} R_{i j} c_{i}
$$

Where $a_{j}$ is row vector of absolute weights for relational strategies, $R_{i j}$ : weights specified o communication matrix, $\mathrm{c}_{\mathrm{i}}$ : column vector for features of strategies, $\mathrm{m}$ : number of technical definitions, and $\mathrm{n}$ : number of costumers' needs. The results obtained by this method are shown in Table 4. As said before, the firm might face with some problems regarding implementation of each strategy. In this regard, constraints are considered as parameters in evaluation and prioritization of strategies. In first step of TOPSIS method, the weights obtained by parameters become non-scale, and non-scale weighted matrix $\mathrm{V}$ is created:

$$
n_{i j}=\frac{r_{i j}}{\sqrt{\sum_{i=1}^{m} r_{i j}{ }^{2}}}
$$

Then, positive and negative ideal options are formed for each criterion by the relations below:

Positive ideal option: $\mathrm{A}^{+}=\left\{\left(\max v_{i j} \mid j \in J\right),\left(\min v_{i j} \mid j \in J^{\prime}\right) \mid \mathrm{i}=1,2 \ldots \mathrm{m}\right\}$

$$
=\left\{V_{1}^{+}, V_{2}^{+}, \ldots, V_{j}^{+}, \ldots, V_{n}^{+}\right\}
$$

Negative ideal option: $\mathrm{A}^{-}=\left\{\left(\min v_{i j} \mid j \in J\right),\left(\max v_{i j} \mid j \in J^{\prime}\right) \mid \mathrm{i}=1,2, \ldots, \mathrm{m}\right\}$

$=\left\{V_{1}^{-}, V_{2}^{-}, \ldots, V_{j}^{-}, \ldots, V_{n}^{-}\right\}$

so that, $J=\{j=1,2, \ldots, n \mid J$ due to profit $\} \quad, \quad J^{\prime}=\{j=1,2, \ldots, n \mid J$ due to cost $\}$

In the next step, distance of ideal option is obtained using Euclidean technique:

$d_{i^{+}}$: Distance of $\mathrm{i}^{\text {th }}$ option from positive ideal $=\left\{\sum_{j=1}^{n}\left(V_{i j}-V_{j}^{+}\right)^{2}\right\}^{0 / 5} \mathrm{i}=1,2 \ldots \mathrm{m}$

$d_{i^{-}}:$Distance of $\mathrm{i}^{\text {th }}$ option from negative ideal $=\left\{\sum_{j=1}^{n}\left(V_{i j}-V_{j}^{-}\right)^{2}\right\}^{0 / 5} \quad \mathrm{i}=1,2 \ldots \mathrm{m}$

At last, relative proximity of each strategy to ideal option is calculated and final priority of relational strategies is obtained (Table 3): 


$$
c l_{i}^{+}=\frac{d_{i^{-}}}{d_{i^{+}}+d_{i^{-}}} \quad ; 0 \leq c l_{i}^{+} \leq 1 \quad ; \quad \mathrm{i}=1,2 \ldots \mathrm{m}
$$

Table 3. Decision matrix to prioritize strategies of relationship with probable costumers

\begin{tabular}{lllllllllll}
\hline strategy & $\begin{array}{l}\text { In } \\
\text { person }\end{array}$ & website & e-mail & chat & $\begin{array}{l}\text { cell } \\
\text { phone }\end{array}$ & SMS & MMS & $\begin{array}{l}\text { Answer } \\
\text { machine }\end{array}$ & fax & post \\
\hline $\begin{array}{l}\text { criterion } \\
\text { Voice of }\end{array}$ & 0.4305 & 0.3829 & 0.3965 & 0.3311 & 0.2204 & 0.3242 & 0.2022 & 0.1932 & 0.1815 & 0.2171 \\
$\begin{array}{l}\text { costumers } \\
\begin{array}{l}\text { Competitor } \\
\text { performance }\end{array}\end{array}$ & 0.4233 & 0.1058 & 0.1587 & 0.2116 & 0.3704 & 0.2116 & 0.2645 & 0.3704 & 0.3175 & 0.4233 \\
$\begin{array}{l}\text { Technical } \\
\text { probability }\end{array}$ & 0.2674 & 0.3198 & 0.2665 & 0.1066 & 0.3198 & 0.4264 & 0.2665 & 0.4264 & 0.3731 & 0.1599 \\
$\begin{array}{l}\text { Positive ideal } \\
\text { Negative }\end{array}$ & 0.3992 & 0.2185 & 0.1760 & 0.1850 & 0.4067 & 0.3614 & 0.2613 & 0.4796 & 0.4485 & 0.4308 \\
$\begin{array}{l}\text { ideal } \\
\mathrm{Cl}_{\text {i+ }}\end{array}$ & 0.2814 & 0.2814 & 0.4063 & 0.4187 & 0.1697 & 0.2798 & 0.3176 & 0.1621 & 0.1245 & 0.2689 \\
\hline
\end{tabular}

According to the results obtained by 2 mentioned approaches, the difference in strategy prioritization is clearly obvious after implementing criteria. Since this strategy is relatively expensive for firm, the face-to-face relationship with costumers would change. Thus, internet communications is considered as the $1^{\text {st }}$ priority for interaction with costumers due to proper cost, better performance of firm compared to competitors, and appropriate technical probability. Table 4 shows home quality matrix and results obtained by prioritization of strategies using QFD and QFD-TOPSIS methods both. Also, Table 5 shows prioritization of strategies of relationship with costumers in several levels of life cycle.

Table 4. Prioritization of strategies of relationship with probable costumers using QFD-TOPSIS

\begin{tabular}{|c|c|c|c|c|c|c|c|c|c|c|c|c|c|}
\hline & & 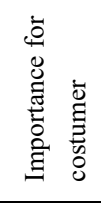 & 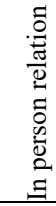 & $\begin{array}{l}\frac{0}{0} \\
\frac{0}{0} \\
3\end{array}$ & : & $\frac{\vec{J}}{0}$ & $\begin{array}{l}\frac{0}{0} \\
\frac{0}{2} \\
0\end{array}$ & $\sum_{\infty}^{\infty}$ & $\sum_{\Sigma}^{\infty}$ & 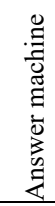 & $\frac{\mathscr{Z}}{2}$ & 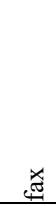 & $\begin{array}{l}\overrightarrow{0} \\
0 \\
\vdots\end{array}$ \\
\hline \multirow{7}{*}{ 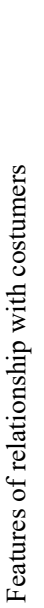 } & $\begin{array}{l}\text { Exact information } \\
\text { about products } \\
\text { and services }\end{array}$ & 4.5294 & (C) & (C) & $\circ$ & $\circ$ & $\circ$ & $\circ$ & $\Delta$ & $\Delta$ & $\Delta$ & $\circ$ & $\Delta$ \\
\hline & Possibility of poll & 4.3529 & (C) & (C) & $\circ$ & $\circ$ & (C) & ○ & $\Delta$ & (C) & $\circ$ & ० & $\circ$ \\
\hline & $\begin{array}{l}\text { Presenting } \\
\text { incentives }\end{array}$ & 4.8235 & (C) & $\circ$ & (C) & ० & $\circ$ & (C) & $\Delta$ & $\Delta$ & $\Delta$ & ० & (C) \\
\hline & $\begin{array}{l}\text { Ease of relation } \\
\text { with firm }\end{array}$ & 4.7647 & $\circ$ & $\circ$ & (C) & (C) & (C) & (C) & (C) & (C) & (C) & $\circ$ & $\Delta$ \\
\hline & Being responsive & 4.6471 & (C) & $\circ$ & (C) & (C) & ○ & $\Delta$ & $\Delta$ & ○ & (C) & $\circ$ & $\circ$ \\
\hline & Cost-effective & 4.5882 & (C) & (C) & (C) & (C) & $\Delta$ & (C) & $\circ$ & (C) & $\Delta$ & $\Delta$ & $\Delta$ \\
\hline & $\begin{array}{ll}\text { Lack } & \text { of } \\
\text { disturbance }\end{array}$ & 4.3529 & $\Delta$ & (C) & (C) & (C) & $\Delta$ & (C) & (C) & (C) & $\Delta$ & (C) & (C) \\
\hline
\end{tabular}




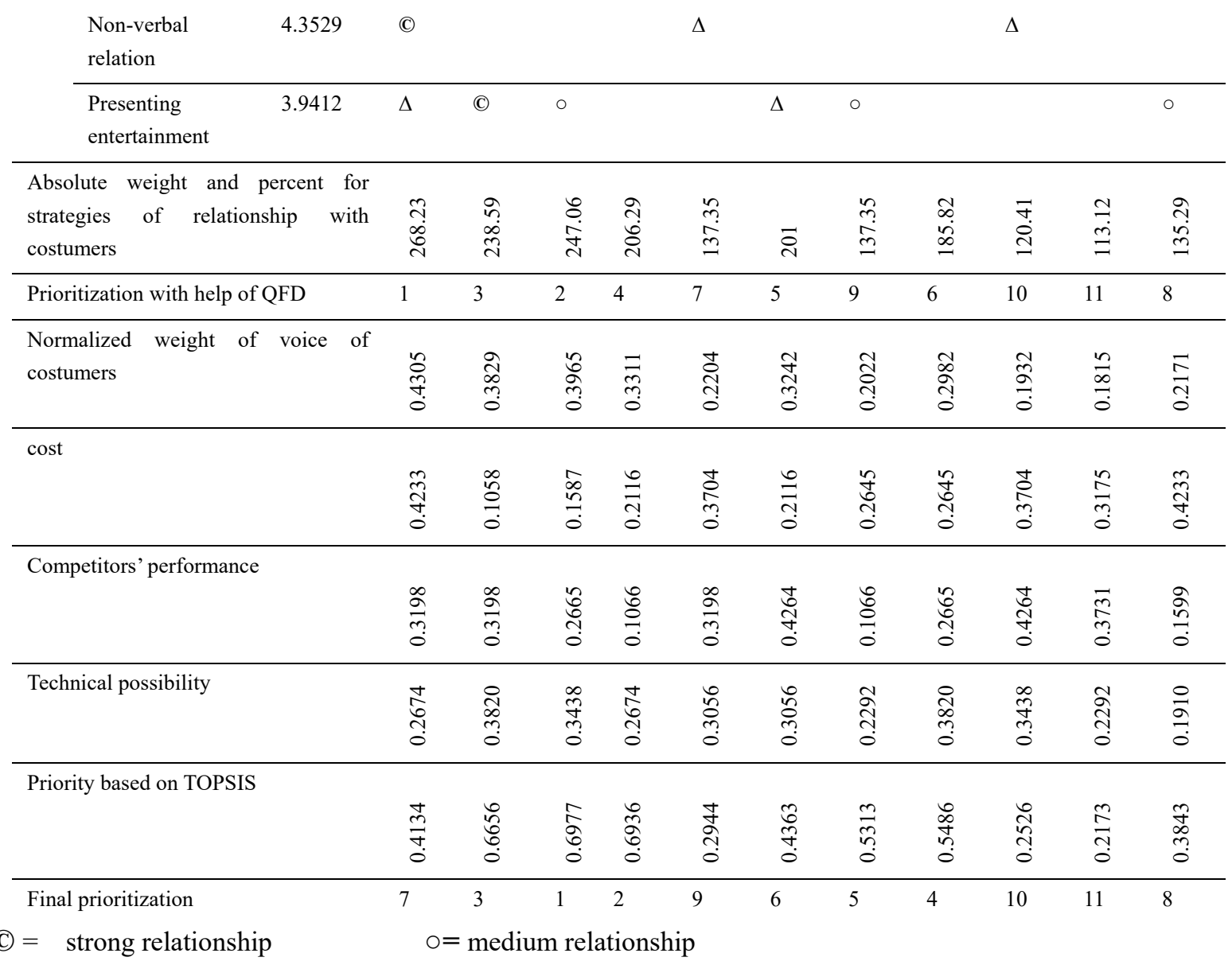

Table 5. Results obtained by prioritization of strategies using QFD and QFD-TOPSIS methods

\begin{tabular}{|c|c|c|c|c|c|c|c|c|c|c|}
\hline \multirow{3}{*}{$\begin{array}{l}\text { Life cycle } \\
\text { and method }\end{array}$} & \multicolumn{2}{|c|}{$\begin{array}{l}\text { Probable } \\
\text { costumer }\end{array}$} & \multicolumn{2}{|c|}{ New costumer } & \multicolumn{2}{|c|}{$\begin{array}{l}\text { Current } \\
\text { costumer }\end{array}$} & \multicolumn{2}{|c|}{$\begin{array}{l}\text { Moving } \\
\text { costumer }\end{array}$} & \multicolumn{2}{|c|}{$\begin{array}{l}\text { Former } \\
\text { costumer }\end{array}$} \\
\hline & QFD & QFD-T & QF & QFD-T & QF & QFD-T & $\mathrm{QF}$ & QFD-T & $\mathrm{QF}$ & QFD-T \\
\hline & & OPSIS & $\mathrm{D}$ & OPSIS & & OPSIS & $\mathrm{D}$ & OPSIS & & OPSIS \\
\hline In person relation & 1 & 7 & 1 & 3 & 1 & 7 & 1 & 11 & 1 & 4 \\
\hline website & 3 & 3 & 6 & 4 & 5 & 3 & 5 & 3 & 4 & 3 \\
\hline chat & 2 & 1 & 5 & 2 & 2 & 2 & 2 & 2 & 2 & 1 \\
\hline e-mail & 4 & 2 & 3 & 1 & 3 & 1 & 3 & 1 & 5 & 2 \\
\hline Cell phone & 7 & 9 & 4 & 8 & 6 & 8 & 7 & 8 & 3 & 8 \\
\hline SSM & 5 & 6 & 2 & 5 & 4 & 6 & 4 & 7 & 6 & 7 \\
\hline MMS & 9 & 5 & 9 & 6 & 9 & 4 & 8 & 4 & 11 & 6 \\
\hline Answer machine & 6 & 4 & 7 & 7 & 7 & 5 & 6 & 5 & 7 & 5 \\
\hline phone & 10 & 10 & 8 & 10 & 8 & 9 & 9 & 9 & 8 & 10 \\
\hline fax & 11 & 11 & 11 & 11 & 10 & 11 & 11 & 10 & 10 & 11 \\
\hline post & 8 & 8 & 10 & 9 & 11 & 10 & 10 & 6 & 9 & 9 \\
\hline
\end{tabular}

\section{Discussion and Results}

The current research was performed in order to develop activities of considered firm in field of relationship with retail costumers, and to identify strategies of their relationship in several levels of life cycle; afterwards, a comprehensive model was presented to determine methods and factors influential on relationship with retailers.

In this research, the relational strategies include in person relationship, posy, phone (call, answer machine, and fax), internet (chat, e-mail, and website), and cell phone (SMS, MMS, and call). Also, 11 relational features were identified as priority needs of customers in several levels of life cycle using Kano integrated model and 
importance-performance matrix (Table 2).

At last, strategies of relationship with costumers are prioritized due to results of priority needs of customers in several levels of life cycle, quality home matrix and final weight obtained for each strategies using integrated QFD-TOPSIS method. Results show that costumers prefer 'in person' relationship to other relational strategies; though this strategy is not in favor of firm because of its relatively high cost.

Results obtained by prioritizing of strategies for probable costumers show that internet communication are in $1^{\text {st }}$ place; this indicates importance of internet for probable costumers and transforming them to regular costumer. In fact, costumers are in search of information and increasing their awareness of firm's products and services. Other priorities of relational strategies include answer machine, MMS and SSM.

The priority of relational strategies for new customers include chat, e-mail, in person relation, website, SSM, and MMS. Since costumers are in beginning of their relation with firm, there must be a specific focus toward them transforming them to permanent costumers. Implementation of priority strategies is an effective move to meet costumers' needs due to possibility of discussion with firm, non-verbal relation, and cost-effectiveness for new costumers.

The priority of relationship with current costumers includes chat, e-mal, website, MMS, SMS, answer machine, and post. Costumers of this level include regular costumers, customers who purchase but are not satisfied, and costumers who are connected with firm inactively. Thus, it is necessary to attend to opinions and viewpoints of costumers and replying them at this evel.

The priority of relationship with moving out costumers includes chat e-mail, website, SMS, MMS, answer machine, and post. This type of costumers might have valuable experiences about firm; they want to lessen their relation with firm substituting it with another one. Receiving comments and replying them has 2 main benefits for organization.

Firstly, it is possible to transform new costumer to permanent ones through understanding and replying to their comments.

Finally, priority of relationship with former costumers includes e-mail, website, in person relation, aster machine, SMS, and MMS. Since in these level costumers leave the firm out to purchase from competitors, so reasons of their exit would have valuable information for firm. Also, it is possible to attract them again using incentives and replying their comments; though it seems not logic to spend for this type of costumers. As said before, Table 5 indicates prioritization of relational strategies about costumers in all levels of life cycle completely.

Results obtained by this study could be an effective action about relationship with retail costumers in all levels of life cycle using a specified system. Different companies enjoy this model to develop their interaction with costumers, and to develop their status in competitive markert using information and database of customers.

\subsection{Recommendations}

1. It is suggested to attend to other demographic features such as age, sex, level of education, etc in order to exact and proper prioritization of relational strategies.

2. It is suggested to study role of culture and use of modern communication strategies due to important role of culture in this field.

3. Each organization needs strategic planning in order to develop its status in different domain. In this regard, it is suggested to present proper strategies and policies to develop relationship with costumers using strategic planning techniques and external-internal analysis of organization.

\section{References}

AL-Majali, F., \& Prigmore, M. (2010). Consumers channel choice behavior in multi-channel environments: what are the influences on consumers to choose the online distribution channels over other alternative offline channels.

Berry, M. A. (2000). Mastering Data Mining: The Art and Science of Customer Relationship Management20002Mastering Data Mining: The Art and Science of Customer Relationship Management. John Wiley \& Sons, ISBN: 0-471-33123-6 Paperback £29.50. Industrial Management \& Data Systems, 100(5), 245-246. http://dx.doi.org/10.1108/imds.2000.100.5.245.2

Blattberg, R. C., Getz, G., \& Thomas, J. S. (2001). Customer equity: Building and managing relationships as valuable assets. Harvard Business Press.

Brechan, I. (2006). The different effect of primary and secondary product attributes on customer satisfaction. 
Journal of Economic Psychology, 27(3), 441-458. http://dx.doi.org/10.1016/j.joep.2005.10.003

Cadotte, E. R., \& Turgeon, N. (1988). Guest Satisfaction.

Dakora, E. A. N. (2007). Multi-channel retailing as a growth strategy for SMME retail businesses in South Africa (Doctoral dissertation, Cape Peninsula University of Technology).

De Felice, F., \& Petrillo, A. (2011). A multiple choice decision analysis: an integrated QFD - AHP model for the assessment of customer needs. International Journal of Engineering, Science and Technology, 2(9), 25-38. http://dx.doi.org/10.4314/ijest.v2i9.63849

Herzberg, F., Mausner, B., \& Snyderman, B. B. (2011). The motivation to work (Vol. 1). Transaction publishers.

Hwang, C. L., \& Yoon, K. (2012). Multiple attribute decision making: methods and applications a state-of-the-art survey (Vol. 186). Springer Science \& Business Media.

Kametani, T., Nishina, K., \& Suzuki, K. (2010). Attractive Quality and Must-be Quality from the Viewpoint of Environmental Lifestyle in Japan. Frontiers in Statistical Quality Control, 9, 315-327. http://dx.doi.org/10.1007/978-3-7908-2380-6_20

Li, Y., Tang, J., Luo, X., \& Xu, J. (2009). An integrated method of rough set, Kano's model and AHP for rating customer requirements' final importance. Expert Systems with Applications, 36(3), 7045-7053. http://dx.doi.org/10.1016/j.eswa.2008.08.036

Murad, J. M. (2009). Improving the Customer Service Level through efficient Business-to-Business Marketing Communication.

Najmi,M, et al. (2009). Prioritization of technical-engineering features of QFD using TOPSIS in Fuzzy mood, Sharif scientific journal, 34, 3-9.

Payne, A., \& Frow, P. (2004). The role of multichannel integration in customer relationship management. Industrial Marketing Management, 33(6), 527-538. http://dx.doi.org/10.1016/j.indmarman.2004.02.002

Sinisalo, J., \& Karjaluoto, H. (2007). Mobile Customer Relationship Management: a communication perspective. International Journal of Electronic Customer Relationship Management, 1(3), 242. http://dx.doi.org/10.1504/ijecrm.2007.017794

Sinisalo, J., Salo, J., Karjaluoto, H., \& Leppaniemi, M. (2006). Managing Customer Relationships through Mobile Medium \&amp;\#8212; Underlying Issues and Opportunities. Proceedings of the 39th Annual Hawaii International Conference on System Sciences (HICSS'06). http://dx.doi.org/10.1109/hicss.2006.262

Swan, J. E., \& Combs, L. J. (1976). Product Performance and Consumer Satisfaction: A New Concept. Journal of Marketing, 40(2), 25. http://dx.doi.org/10.2307/1251003

Thakkar, J., Deshmukh, S. G., \& Shastree, A. (2006). Total quality management (TQM) in self-financed technical institutions. Quality Assurance in Education, 14(1), 54-74. http://dx.doi.org/10.1108/09684880610643610

Tsiptsis, K. K., \& Chorianopoulos, A. (2011). Data mining techniques in CRM: inside customer segmentation. John Wiley \& Sons.

Zhang, P., \& Von Dran, G. M. (2000). Satisfiers and dissatisfiers: A two-factor model for website design and evaluation. Journal of the American society for information science, 51(14), 1253-1268. http://dx.doi.org/10.1002/1097-4571(2000)9999:9999<::AID-ASI1039>3.0.CO;2-O

\section{Copyrights}

Copyright for this article is retained by the author(s), with first publication rights granted to the journal.

This is an open-access article distributed under the terms and conditions of the Creative Commons Attribution license (http://creativecommons.org/licenses/by/4.0/). 